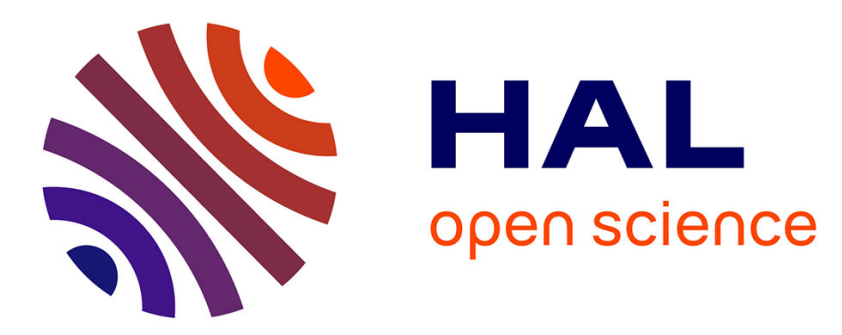

\title{
Emplacement mechanism of Late Triassic granitic Dushan pluton, North China and its tectonic implications
}

\author{
Huabiao Qiu, Wei Lin, Yan Chen, Michel Faure
}

\section{To cite this version:}

Huabiao Qiu, Wei Lin, Yan Chen, Michel Faure. Emplacement mechanism of Late Triassic granitic Dushan pluton, North China and its tectonic implications. EGU General Assembly 2020, May 2020, Online, France. 10.5194/egusphere-egu2020-5668 . hal-03554434

\author{
HAL Id: hal-03554434 \\ https://hal.science/hal-03554434
}

Submitted on 3 Feb 2022

HAL is a multi-disciplinary open access archive for the deposit and dissemination of scientific research documents, whether they are published or not. The documents may come from teaching and research institutions in France or abroad, or from public or private research centers.
L'archive ouverte pluridisciplinaire HAL, est destinée au dépôt et à la diffusion de documents scientifiques de niveau recherche, publiés ou non, émanant des établissements d'enseignement et de recherche français ou étrangers, des laboratoires publics ou privés. 
EGU2020-5668, updated on 03 Feb 2022

https://doi.org/10.5194/egusphere-egu2020-5668

EGU General Assembly 2020

(c) Author(s) 2022. This work is distributed under

the Creative Commons Attribution 4.0 License.

\title{
Emplacement mechanism of Late Triassic granitic Dushan pluton, North China and its tectonic implications
}

\author{
Huabiao Qiu ${ }^{1,2,3}$, Wei Lin ${ }^{1,3}$, Yan Chen², and Michel Faure ${ }^{2}$ \\ ${ }^{1}$ State Key Laboratory of Lithospheric Evolution, Institute of Geology and Geophysics, Chinese Academy of Sciences, \\ Beijing100029, China \\ 2Université d'Orléans, ISTO, CNRS/INSU, UMR 7327, Orléans, France \\ ${ }^{3}$ College of Earth and Planetary Sciences, University of Chinese Academy of Sciences, Beijing100049, China
}

To better understand the Late Triassic tectonic setting in the northern North China Craton (NCC), a multidisciplinary investigation, including structural geology, geochronology, anisotropy of magnetic susceptibility (AMS) and gravity modeling, has been carried out in the Dushan pluton. The Dushan pluton consists of monzogranite and biotite-rich facies along the pluton margin without sharp contact between them. The granite varies southwestwards from isotropic texture to arcuate gneissic structures, with locally mylonitic structures. The intensity of solid-state deformation increases southwestwards across the pluton, leaving preserved magmatic fabrics in the northeastern part. The compatible outward dipping magmatic and solid-state magnetic fabrics, together with mesoscopic fabrics, define an elliptic dome-like pattern with a NE-SW oriented long axis, despite the fabrics dip inwards in the southeastern margin of the pluton. Combining gravity modeling, the Dushan pluton presents an overall tabular or tongue-like shape with a northeastern root. The magnetic lineations nearly strike NE-SW, concordant with the stretching lineations observed in the mylonitic zones. We propose the emplacement mode that the Dushan pluton emplaced southwards through the feeder zone in its northeast, beginning probably with a sill. The later successive magma batches may laterally and upwardly inflate, deform and even recrystallize the former cool-down magma. This inflation forms an arcuate, gneissic to mylonitic foliation in the southwestern margin. The Dushan pluton is considered as typically post-tectonic in emplacement, recording a Late Triassic post-tectonic setting of the northern NCC. 